\title{
Chemical composition, acetylcholinesterase inhibitory and antifungal activities of Pera glabrata (Schott) Baill. (Euphorbiaceae)
}

\author{
ELAINE MONTEIRO CARDOSO-LOPES ${ }^{1,3}$, DAISY MARIA BENTES DE PAULA ${ }^{1}$, \\ FAUSTO ERRITTO BARBO ${ }^{1}$, AMANDA DE SOUZA², CECÍLIA TERUMI TERADAIRA BLATT ${ }^{1}$, \\ LUCE MARIA BRANDÃO TORRES ${ }^{1}$ and MARIA CLÁUDIA MARX YOUNG ${ }^{1}$
}

(received: September 4, 2008; accepted: September 23, 2009)

\begin{abstract}
Chemical composition, acetylcholinesterase inhibitory and antifungal activities of Pera glabrata (Schott) Baill. (Euphorbiaceae)). Pera glabrata (Schott) Baill. was selected for this study after showing a preliminary positive result in a screening of Atlantic Forest plant species in the search for acetylcholinesterase inhibitors and antifungal compounds. The bioassays were conducted with crude ethanol extract of the leaves using direct bioautography method for acetylcholinesterase and antifungal activities. This extract was partitioned with hexane, chloroform and ethyl acetate solvents. The active chloroform fraction was submitted to silica gel chromatography column affording 12 groups. Caffeine, an alkaloid, which showed detection limits of 0.1 and $1.0 \mu \mathrm{g}$ for anticholinesterasic and antifungal activities, respectively, was isolated from group nine. After microplate analyses, only groups four, nine, 10,11 and 12 showed acetylcholinesterase inhibitory activity of $40 \%$ or higher. The group 12 was purified by preparative layer chromatography affording four sub-fractions. Two sub-fractions from this group were analyzed by gas chromatography-mass spectrometry and gas chromatography-flame ionization detector. The first sub-fraction showed anticholinesterasic activity and contained two major compounds: 9-hydroxy-4-megastigmen-3-one (84\%) and caffeine (6\%). The second sub-fraction presented five major compounds identified as 9-hydroxy-4-megastigmen-3-one, isololiolide, (-) loliolide, palmitic acid and lupeol and did not show activity.
\end{abstract}

Key words - 9-hydroxy-4-megastigmen-3-one, biological activities, caffeine, Euphorbiaceae

Resumo - (Composição química, atividades inibidora da acetilcolinesterase e antifúngica de Pera glabrata (Schott) Baill. (Euphorbiaceae)). Pera glabrata (Schott) Baill. foi selecionada para este estudo a partir de uma triagem de espécies vegetais da Mata Atlântica na busca de substâncias com atividades anticolinesterásica e antifúngica. A técnica da bioautografia direta foi utilizada para a deteç̧ão das atividades anticolinesterásica e antifúngica. O extrato etanólico bruto obtido das folhas foi particionado com hexano, clorofórmio e acetato de etila. A fração clorofórmica ativa foi fracionada por cromatografia em coluna de sílica gel fornecendo 12 grupos. Do grupo nove foi isolado o alcalóide cafeína com limites de detecção de 0,1 e $1,0 \mu \mathrm{g}$ para as atividades anticolinesterásica e antifúngica, respectivamente. Após bioensaio em microplaca, somente os grupos quatro, nove, 10, 11 e 12 apresentaram inibição da acetilcolinesterase maior ou igual a 40\%. O grupo 12 foi purificado por cromatografia em camada delgada preparativa de sílica gel fornecendo quatro sub-frações. Duas sub-frações deste grupo foram analisadas por cromatografia a gás-espectrometria de massas e cromatografia a gás com detector de ionização de chama. A primeira sub-fração contém dois compostos majoritários: 9-hidroxi-4-megastigmen-3-ona (78\%) e cafeína $(6 \%)$, e apresentou atividade anticolinesterásica. A segunda sub-fração contém cinco compostos principais identificados como 9-hidroxi-4-megastigmen-3-ona, isololiolida, (-) loliolida, ácido palmítico e lupeol e não apresentou atividade.

Palavras-chave - 9-hidroxi-4-megastigmen-3-ona, atividades biológicas, cafeína, Euphorbiaceae

\section{Introduction}

Pera glabrata (Schott) Baill. is a species of the family Euphorbiaceae. This family presents cosmopolitan distribution, being more abundant in the tropical and subtropical regions, consisting of about 300 genus and 7,500 species (Cronquist 1981). In Brazil the family

\footnotetext{
1. Instituto de Botânica, Seção de Fisiologia e Bioquímica de Plantas, Caixa Postal 3005, 01061-970 São Paulo, SP, Brazil.

2. Universidade de São Paulo, Instituto de Química, Laboratório de Química de Produtos Naturais, 05508-000 São Paulo, SP, Brazil.

3. Corresponding author: elaine.mlopes@ig.com.br
}

is represented by 72 genera and about 1,100 species present in all types of vegetation (Barroso et al. 1984). Euphorbiaceae are very well represented in the Brazilian flora, with species used as food (cassava - Manihot esculenta Crantz), as oil producer (castor-oil - Ricinus communis L.; tung-oil tree-Aleurites fordii Hemsl.), as rubber producer (rubber tree - Hevea brasiliense Müll. Arg.), as phytotherapeutic and as ornamental plants too (crown-of-thorns - Euphorbia milii Des Moul.) (Joly 1976, Mors \& Rizzini 1966).

Pera benensis Rusby is considered a medicinal plant used in folk medicine by Chimane Indians from Bolivia for the specific treatment of cutaneous 
leishmaniasis popularly known as espundia (Fournet et al. 1992).

Pera glabrata is popularly known as tamanqueira, sapateiro, pau-de-sapateiro and seca-ligeiro (Lorenzi 2002). This evergreen and heliophyte species, which can reach 8.0 to $10.0 \mathrm{~m}$ height, is native to seasonal semi-deciduous forest and can be found in well-drained lands of hilltops as well as in riparian forest (Lorenzi 2002).

Plants are a valuable source of new natural products. Only a small proportion of the several hundred thousand plant species around the globe has been investigated both phytochemical and pharmacologically. The crucial factor for the ultimate success of an investigation into bioactive plant constituents is thus the selection of the plant material (Hostettmann et al. 1995). In view of the large number of plant species potentially available for study, it is essential to have efficient systems for the rapid chemical and biological screening of the plant extracts selected for investigation. Isolation of pure and pharmacologically active constituents from plants remains a long process and requires the collaboration of botanists, pharmacologists, chemists, pharmacognosists and toxicologists (Hamburger \& Hostettmann 1991, Hostettmann 1998).

All the vegetal extracts or pure compounds isolated in phytochemical laboratories should be submitted to a large number of bioassays (Hostettmann 1998). So, the quick and efficient detection of biologically active substance is an aspect of great importance in the process of its discovery (Rios et al. 1988).

The search for antifungal drugs has received attention especially as a result of the crescent incidence of opportunist mycosis, mainly associated with AIDS and treatment with immunosuppressive drugs. There are few antifungal agents indicated for the systemic mycosis treatment but their efficacy is limited (Hamburger \& Hostettmann 1991).

The advances obtained in the comprehension of evolution and molecular aspects of genesis of the Alzheimer's disease (AD) have shown that the use of acetylcholinesterase inhibitors must be the most efficient way of controlling its evolution and recovering of the presented symptoms (Francis et al. 1999, Quik \& Jeyarasasingam 2000). Despite the fact that it is not used in folk medicine, Pera glabrata was chosen for this study based on the screening for the anticholinesterasic and antifungal activities assayed in our laboratory. The focus of this work is to study chemical and biological aspects of Pera glabrata extracts with potential anticholinesterasic and antifungal activities.

\section{Material and methods}

Study area - The Parque Estadual das Fontes do Ipiranga (PEFI) is located in the southeast region of the Municipal District of São Paulo in the frontier of the Municipal District of Diadema and several other districts of São Paulo and holds an area of approximately $526.38 \mathrm{ha}$. The flora is represented by native vegetation and characterized as an extension of the Atlantic hillside forest, without predominance of any plant family in particular. Some specimens of Pera glabrata (Schott) Baill. can be found in this park.

Plant material - Pera glabrata leaves were collected in PEFI in March 2006 and identified by Dr Inês Cordeiro, SP Herbarium, Instituto de Botânica. A voucher specimen (Cordeiro 1775) is deposited at the SP.

Preparation of extract - After drying and crushing, the leaves $(3.5 \mathrm{~kg})$ were extracted with $92 \%$ ethanol $(0.5 \mathrm{~L}$ : $0.5 \mathrm{~kg}, 10$ days) six times at room temperature. The extracts were filtered and concentrated under vacuum in a rotary evaporator and dried in a steam bath at $50{ }^{\circ} \mathrm{C}$. The crude ethanol extract $(104.90 \mathrm{~g})$ was dissolved in methanol-water (6:4), and partitioned with hexane $(150 \mathrm{~mL}$, seven times), chloroform $(150 \mathrm{~mL}$, six times) and ethyl acetate $(150 \mathrm{~mL}$, six times) to yield hexane (37.43 g), chloroform (10.14 g), ethyl acetate $(6.14 \mathrm{~g})$ and water-methanol $(24.03 \mathrm{~g})$ fractions. The antifungal and anticholinesterasic activities assays of these fractions were performed by direct bioautography and microplate assays, respectively (Homans \& Fuchs 1970, Rhee et al. 2001).

Bioassay guided fractionation - The chloroform fraction $(10.14 \mathrm{~g})$ was fractionated using column chromatography (CC) over silica gel $(0.063-0.200 \mathrm{~mm})$ using $\mathrm{CHCl}_{3}-\mathrm{MeOH}$ gradient solvent system, affording 88 fractions ( $100 \mathrm{~mL}$ each) that were monitored by TLC silica gel eluted with $\mathrm{CHCl}_{3}$ : $\mathrm{MeOH}(9: 1)$ and visualized under ultraviolet light (UV) at $254 \mathrm{~nm}$ and $366 \mathrm{~nm}$. Fractions were pooled according to their inhibition of acetylcholinesterase and antifungal activities and the chromatographic profile on thin layer chromatography affording 12 groups. The groups were classified as G1 (fractions 1-16), G2 (17-21), G3 (22), G4 (23), G5 (24-27), G6 (28-32), G7 (33-40), G8 (41-45), G9 (46-48), G10 (49-51), G11 (52-62) and G12 (63-88). The groups G9, G10, G11 and G12 were the most active and presented crystals that were identified as described below. The active group G12 was further fractionated by preparative TLC (hexane-EtOAc, 4:6) giving four sub-fractions. The second and third sub-fractions were analyzed by gas chromatography and mass spectrometry (GC/MS).

Gas Chromatography / Mass Spectrometry (GC/MS) and CG/ FID - The identification of compounds was achieved by gas chromatography and mass spectrometry (GC/MS), using an Agilent GC (6890 Series) - quadrupole MS system (5973), with a fused silica capillary column $(30 \mathrm{~m} \times 0.25 \mathrm{~mm}$ 
$\times 0.25 \mu \mathrm{m}$, coated with DB-5), EI operating at $70 \mathrm{eV}$. Injector and detector temperatures were set at $250{ }^{\circ} \mathrm{C}$. The oven temperature program was $40^{\circ} \mathrm{C}$ for $1 \mathrm{~min}, 40-240{ }^{\circ} \mathrm{C}$ at $10^{\circ} \mathrm{C} \mathrm{min}-1$ and helium was employed as carrier gas $\left(1 \mathrm{~mL} \mathrm{~min}^{-1}\right)$ and injector FID temperature $250{ }^{\circ} \mathrm{C}$, injection volume $2 \mu$. The compound identification was performed by comparing mass spectra to a standard compound (caffeine), library Wiley 275 and literature data. The anticholinesterasic and antifungal activities of each group were tested and the most active groups presented crystals identified as caffeine by ${ }^{1} \mathrm{H}(300 \mathrm{MHz})$ and ${ }^{13} \mathrm{C} \mathrm{NMR}\left(\mathrm{CDCl}_{3}-75 \mathrm{MHz}\right)$ spectra obtained in a Bruker DRX-300 spectrometer. The identification of the crystals was based on comparison with data of ${ }^{1} \mathrm{H}$ - and ${ }^{13} \mathrm{C}$ NMR spectra (Wehrli \& Nishida 1979, Sousa et al. 1991). The ${ }^{1} \mathrm{H}$ NMR spectrum of crystal presented chemical shift $(\delta)$ signals at $\delta 7.57(1 \mathrm{H}, s, \mathrm{CH}), \delta 4.00\left(3 \mathrm{H}, s, \mathrm{NCH}_{3}\right), \delta 3.58$ $\left(3 \mathrm{H}, s, \mathrm{NCH}_{3}\right), \delta 3.40\left(3 \mathrm{H}, s, \mathrm{NCH}_{3}\right)$ and ${ }^{13} \mathrm{C} \mathrm{NMR}$ spectrum presented signals at $\delta 141.3(\mathrm{CH}), \delta 33.4\left(\mathrm{NCH}_{3}\right), \delta 29.6$ $\left(\mathrm{NCH}_{3}\right), \delta 27.7\left(\mathrm{NCH}_{3}\right)$. The GC/MS analysis presented a total ions chromatogram (TIC) with retention time (RT) = $18.25 \mathrm{~min}$ of $\mathrm{m} / \mathrm{z} 194$ [M+], 194 (100), 109 (55), 82 (25), 67 (38), 55 (33) confirming the caffeine structure.

Acetylcholinesterase activity by bioautography - The procedure recently reported by Marston et al. (2002) was used for this bioassay. Briefly, acetylcholinesterase type V (Sigma, product no. C 2888, $1000 \mathrm{U}$ ) was dissolved in Tris-hydrochloric acid buffer ( $\mathrm{pH}$ 7.8) and stabilized by the addition of bovine serum albumin fraction V $(0.1 \%$, Sigma, product no. A-4503). TLC layers were spotted with $200 \mu \mathrm{g}$ of plant extract, $50 \mu \mathrm{g}$ of fractions groups (G1 to G12) and $1 \mu \mathrm{g}$ of galanthamine (Sigma) was used as positive control. TLC layers were developed with $\mathrm{CHCl}_{3}: \mathrm{MeOH}(9: 1, \mathrm{v} / \mathrm{v})$ and subsequently dried. The plates were then sprayed with the enzyme solution $\left(6.66 \mathrm{U} \mathrm{mL}^{-1}\right)$, thoroughly dried and incubated at $37^{\circ} \mathrm{C}$ for $20 \mathrm{~min}$ in moist atmosphere. Enzyme activity was detected by spraying the plate with a solution consisting of $0.25 \%$ of 1-naphtyl acetate in $\mathrm{EtOH}(5 \mathrm{~mL})$ plus $0.25 \%$ aqueous solution of Fast Blue B salt $(20 \mathrm{~mL})$. Potential acetylcholinesterase inhibitors appeared as clear zones on a purple colored background.

Antifungal activity - Cladosporium cladosporioides (Fresen.) G.A. de Vries CCIBt 140 from the live collection of IBt was grown in potato dextrose agar for 12 days until sporulation. Ten microliters of a solution corresponding to $400 \mu \mathrm{g}$ of crude extracts and $50 \mu \mathrm{g}$ of fraction groups (G1 to G12) were applied on Al-backed silica gel $\mathrm{F}_{254}$ TLC layers (Merck) and run with $\mathrm{CHCl}_{3}: \mathrm{MeOH}(9: 1 \mathrm{v} / \mathrm{v})$. The solvent was then completely removed and the plates were sprayed with a conidia suspension of $C$. cladosporioides $\left(\geq 10^{6}\right.$ conidia $\mathrm{mL}^{-1}$ ) in a glucose and salt solution (Homans \& Fuchs 1970, Rahalison et al. 1994) and incubated for $48 \mathrm{~h}$ at $28^{\circ} \mathrm{C}$. After incubation, clear inhibition zones appeared against the dark green background of the chromatogram. Nystatin $1.0 \mu \mathrm{g}$ (Sigma) was used as standard control. These bioautographic assays were performed in triplicate.
Acetylcholinesterase activity by microplate assay Acetylcholinesterase activity was evaluated using a 96-well microplate reader (Rhee et al. 2001) based on Ellman's method (Ellman et al. 1961). In this method the enzyme hydrolyzes the substrate acetylthiocholine resulting in the production of thiocholine which reacts with 5,5'-dithio-bis(2-nitrobenzoic acid) (DTNB, Sigma) to produce 2-nitrobenzoate-5mercaptothiocholine and 5-thio-2-nitrobenzoate which can be detected at $405 \mathrm{~nm}$. In the 96-well plates, $25 \mu 1$ of $15 \mathrm{mM}$ acetylthiocholine iodide (ATCI, Sigma) in water, $125 \mu 1$ of $3 \mathrm{mM}$ DTNB in buffer C, $50 \mu \mathrm{l}$ of buffer B, $25 \mu \mathrm{l}$ of plant extract sample $\left(20 \mathrm{mg} \mathrm{ml}^{-1}\right.$ of crude extract in $\mathrm{MeOH}$ diluted 10 times with buffer A and 10 times in well to give a final concentration of $0.2 \mathrm{mg} \mathrm{ml}^{-1}$ ) were added and the absorbance was measured at $405 \mathrm{~nm}$ every $30 \mathrm{~s}$ for three times. Then $25 \mu \mathrm{l}$ of $0.22 \mathrm{U} \mathrm{ml}^{-1}$ of the enzyme acetylcholinesterase (AChE, Sigma) were added and the absorbance was read again every $10 \mathrm{~min}$ for two times. Any increase in absorbance due to the spontaneous hydrolysis of the substrate was corrected by subtracting the rate of the reaction before the addition of the enzyme from the rate of the enzyme reaction. Enzyme activity was calculated as a percentage compared to an assay using a buffer without any inhibitor $(10 \% \mathrm{MeOH}$ in Buffer A). The following buffers were used: buffer A $(50 \mathrm{mM}$ Tris$\mathrm{HCl}, \mathrm{pH}$ 8), buffer B (50 mM Tris- $\mathrm{HCl}, \mathrm{pH} 8$, containing $0.1 \%$ bovine serum albumin V fraction - BSA, Sigma), and buffer $\mathrm{C}(50 \mathrm{mM}$ Tris- $\mathrm{HCl}$, $\mathrm{pH} 8$, containing $0.1 \mathrm{M} \mathrm{NaCl}$ and $\left.0.02 \mathrm{M} \mathrm{MgCl}_{2} \cdot 6 \mathrm{H}_{2} \mathrm{O}\right)$.

Results expression - Results from bioautographic assays were expressed as retention factor (Rt) of zones of growth inhibition of $C$. cladosporioides and inhibition zones of acetylcholinesterase. The quantitative results of acetylcholinesterase inhibition were represented as means \pm standard error (SE) of the mean of one typical experiment performed in triplicate. The AChE inhibitory data were analyzed with the software package Prism version 3.0 (Graph Pad Inc., San Diego, USA). $\mathrm{IC}_{50}$ value is the mean \pm SE of determinations performed in triplicate.

\section{Results and discussion}

As a result of the investigation of the crude ethanol extract of the leaves of $P$. glabrata evaluated for its antifungal and anticholinesterasic activities, it was found that this extract was active against $C$. cladosporioides and also showed anticholinesterasic activity.

The crude ethanol extract (104.90 g) partitioned between $80 \%$ aqueous $\mathrm{MeOH}$ and hexane, chloroform and ethyl acetate yielded fractions representing 35.4\%, $9.5 \%$ and $5.8 \%$ of the total extract, respectively. Only the chloroform fraction showed significant antifungal and anticholinesterasic activities by TLC method at $\mathrm{Rf}$ 0.61. In microplate assay this fraction inhibited 
the enzyme by $42 \%$ and it was selected for further purification (figure 1). It was fractionated by chromatographic procedure and the antifungal and anticholinesterasic activities of each fraction were tested by TLC bioassay. With $\mathrm{CHCl}_{3}$ as eluent, 80 fractions (F1-F80) were obtained, and with $\mathrm{CHCl}_{3} / \mathrm{MeOH}$ (99:1), eight fractions were obtained (F81-88). These fractions were pooled according to their chromatographic profile and anticholinesterasic activity in microplate assay, into 12 groups: G1 (1-16, $4.0 \mathrm{mg}), \mathrm{G} 2$ (17-21, $6.2 \mathrm{mg}), \mathrm{G} 3$ (22, $4.6 \mathrm{mg}), \mathrm{G} 4$

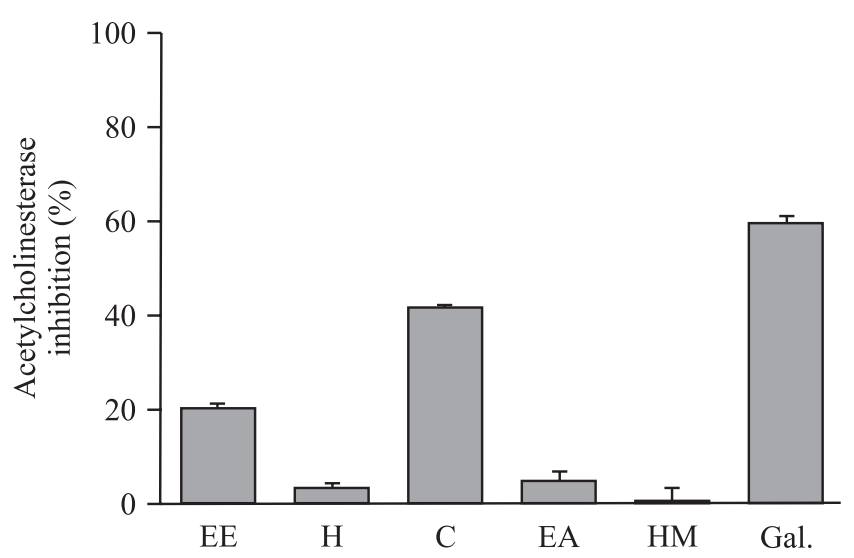

Figure 1. Acetylcholinesterase inhibitory activity of ethanol extract $\left(200 \mu \mathrm{g} \mathrm{mL}^{-1}\right)$, different fractions $\left(100 \mu \mathrm{g} \mathrm{mL} L^{-1}\right)$ obtained from purification of ethanol extract of Pera glabrata and galanthamine $(1 \mu \mathrm{M})$ (values represent the mean of triplicates with standard error). ( $\mathrm{EE}=$ ethanol extract; $\mathrm{H}=$ hexane fraction; $\mathrm{C}=$ chloroform fraction; $\mathrm{EA}=$ ethyl acetate fraction; $\mathrm{HM}=$ hydromethanolic fraction; Gal. = Galanthamine).
(23, $37.9 \mathrm{mg}), \mathrm{G} 5$ (24-27, $882.0 \mathrm{mg}), \mathrm{G} 6$ (28-32, $64.8 \mathrm{mg}), \mathrm{G} 7$ (33-40, $88.9 \mathrm{mg}), \mathrm{G} 8(41-45,125.2 \mathrm{mg})$, G9 (46-48, $141.0 \mathrm{mg}), \mathrm{G} 10$ (49-51, $228.5 \mathrm{mg})$, G11 (52-62, $471.4 \mathrm{mg})$ and $\mathrm{G} 12(63-88,231.4 \mathrm{mg})$. The groups $\left(50 \mu \mathrm{g} \mathrm{mL}^{-1}\right)$ that inhibited the enzyme at $40 \%$ or at higher percentages were G4 (47 $\pm 2.7 \%)$, G9 (53 $\pm 0.2 \%), \mathrm{G} 10(59 \pm 0.4 \%), \mathrm{G} 11(61 \pm 2.4 \%)$, and $\mathrm{G} 12$ (64 $\pm 0.8 \%$ ) (figure 2). Groups G3, G4, G6, G9, G10, G11 and G12 also displayed strong antifungal activity when $50 \mu \mathrm{g}$ were tested by TLC bioassay (figure 3).

The alkaloid caffeine was isolated from group nine to 12 as a white solid crystal with a yield of $0.02 \%$ leaf extract. The identification of this alkaloid was performed by ${ }^{1} \mathrm{H}$ and ${ }^{13} \mathrm{C}$ NMR, GC-MS and compared with a standard compound (caffeine).

To establish detection limits (DL) for the bioautographic assay, i.e the concentration that produced the spot with the least observable whiteness, varying concentrations of galanthamine and physostigmine (eserine), known acetylcholinesterase inhibitors, were applied onto a TLC plate and compared with caffeine. Galanthamine inhibited the enzyme up to $0.03 \mu \mathrm{g}$, while the least amount of physostigmine required for activity was $0.003 \mu \mathrm{g}$. The alkaloid caffeine inhibited the enzyme up to $0.1 \mu \mathrm{g}$ and these results are in accordance with the bioautographic results obtained by Marston et al. (2002). The concentration of caffeine necessary to produce $50 \%$ of acetylcholinesterase inhibition $\left(\mathrm{IC}_{50}\right)$ was $17.7 \mu \mathrm{g} \mathrm{mL}^{-1}$. These in vitro results are in accordance with recent researches that demonstrated that the consumption of caffeine-containing beverages appeared to possibly confer some protective effects against Alzheimer's disease (Maia \& De Mendouca

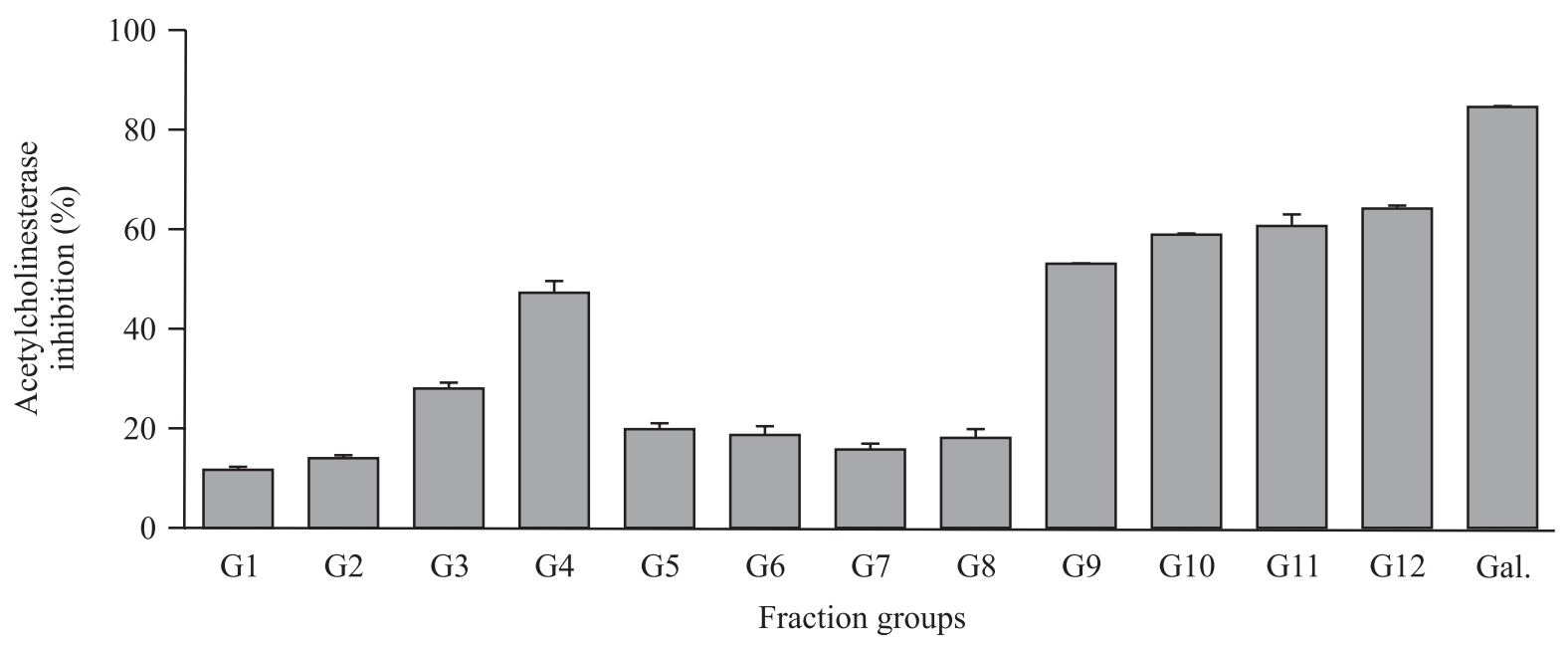

Figure 2. Acetylcholinesterase inhibitory activity of different fraction groups, G1 to G12 (50 $\left.\mu \mathrm{g} \mathrm{mL}^{-1}\right)$, obtained from chloroform fraction of Pera glabrata and galanthamine $1 \mu \mathrm{M}$ (Gal.) (values represent the mean of triplicates with standard error). 
$\begin{array}{lllllllllllll}\text { G1 } & \text { G2 } & \text { G3 } & \text { G4 } & \text { G5 } & \text { G6 } & \text { G7 } & \text { G8 } & \text { G9 } & \text { G10 } & \text { G11 } & \text { G12 } & \text { Nist. }\end{array}$

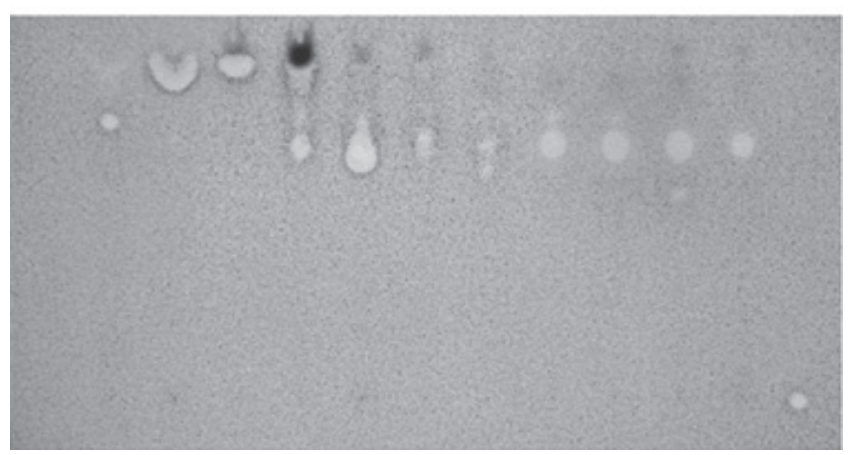

Figure 3. Antifungal activity of different fraction groups, G1 to $\mathrm{G} 12\left(50 \mu \mathrm{g} \mathrm{mL}^{-1}\right)$ obtained from chloroform fraction of Pera glabrata and nystatin $1 \mu \mathrm{g}$ (Nist.).

2002). Caffeine has many molecular targets: release calcium through activating the ryanodine-sensitive calcium release channels of the endoplasmic and sarcoplasmic reticulum, inhibit phosphodiesterase and block adenosine $A_{1}$ and $A_{2 A}$ receptors (Daly 2007). In studies with model Alzheimer's mice, chronic intake of caffeine protected against cognitive impairment and resulted in reduced brain levels of $\beta$-amyloid protein (Arendash et al. 2006). Our data reinforce those obtained with the in vivo model, in which caffeine inhibits the enzyme acetylcholinesterase, improving the symptoms of the disease and being capable of retarding the neurodegenerative process in Alzheimer's disease. A study performed by Silva et al. (2008) showed that caffeine maternal treatment increased hippocampal
AChE activity in 21-day-old pups, with no effect on mRNA expression.

For the antifungal activity against Cladosporium cladosporioides the detection limit of caffeine was $1 \mu \mathrm{g}$. Methylxanthines like caffeine may have ecological significance to the plant that produces them, influencing the interactions between organisms and benefiting the plant adaptation to adverse environment. The content of methylxanthines may be influenced by the stage of plant development, due to seasonal alterations, interventions of agronomic procedures and other factors (Rates 2001). The "chemical defense theory" proposes that the high concentrations of caffeine in young leaves, fruits and flower buds of a species act as a defense to protect young soft tissues from pathogens and herbivores (Ashihara et al. 2008). Nathanson (1984) described that caffeine is naturally an insecticide, larvicide and fungicide at concentrations found in plants. Another work realized by Yuvamoto \& Said (2007) has shown that caffeine and caffeic acid exert a negative effect on germination, nuclear duplication cycle and on formation of the first septum of Aspergillus nidulans (Eidam) G. Winter. Ecological and pharmacological studies have demonstrated that caffeine has a broad range of effects, both as a research tool and as a key structure for the synthesis of molecules with therapeutic value (Daly 2007).

The group G12 was submitted to silica gel preparative chromatography affording four sub-fractions. The second sub-fraction $(13.6 \mathrm{mg})$ with a blue fluorescence (UV $366 \mathrm{~nm}$ ) showed two major compounds (figure 4) when analyzed by gas chromatography- FID and gas

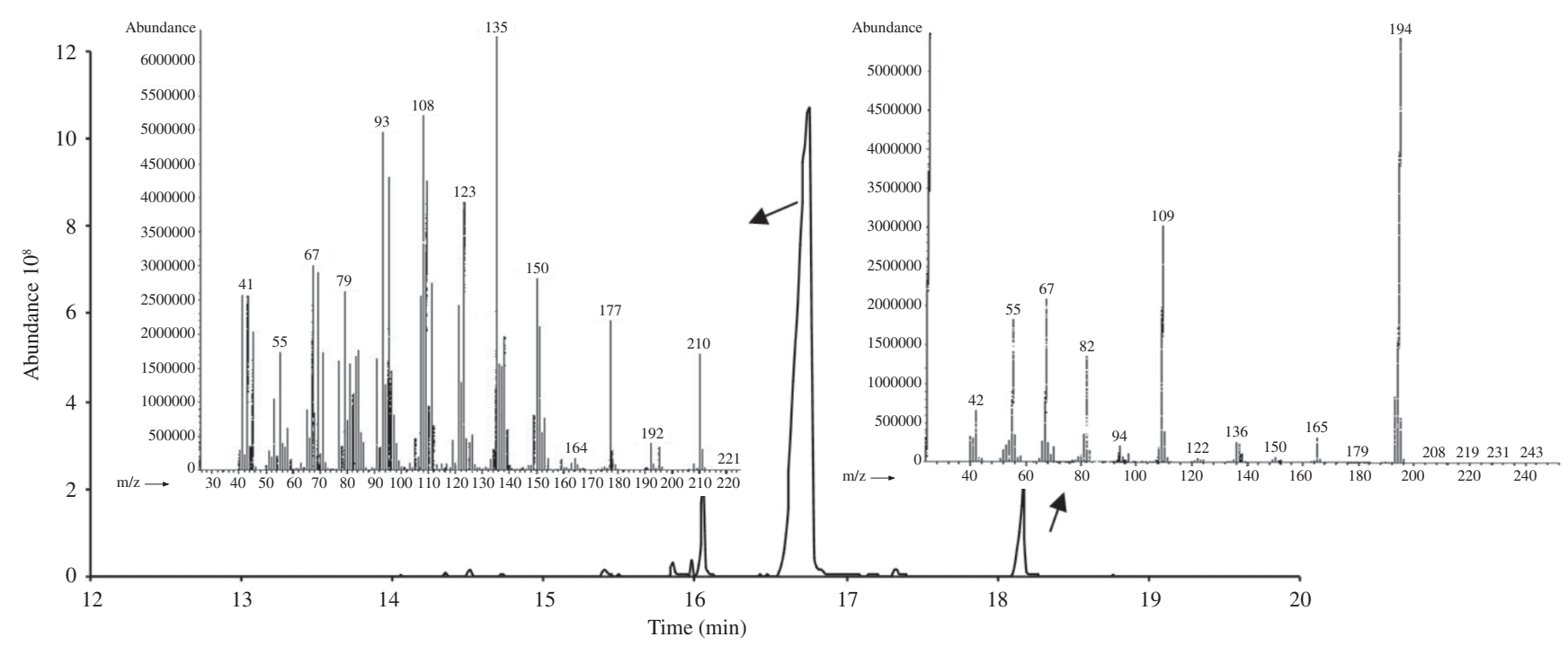

Figure 4. Total ion chromatogram (TIC) and mass spectra of 9-hydroxy-4-megastigmen-3-one $(\mathrm{m} / \mathrm{z} 210)$ and caffeine $(\mathrm{m} / \mathrm{z}$ 194). The fragmentation patterns of these substances are indicated by arrows inside the chromatogram. 
chromatography- mass spectrometry. The ion at $\mathrm{m} / \mathrm{z}$ $210(\mathrm{RT}=16.8 \mathrm{~min})$ had the fragmentation pattern $\mathrm{m} / \mathrm{z}$ $210\left[\mathrm{M}^{+}\right]$, (percentage of relative intensity) $135(100)$, 109 (66), 108 (80), 95 (66), 93 (76) and corresponded to literature data of 9-hydroxy-4-megastigmen-3-one (Miyase et al. 1988), and caffeine (RT $=18.2 \mathrm{~min}$, 6\%, m/z $194\left[\mathrm{M}^{+}\right] 194$ (100), 109 (55),82 (25), 67 (38), 55 (33). Megastigman compounds were previously isolated from Glochidion zeylanicum (Gaertn.) A. Juss. (Euphorbiaceae) besides species of Apocynaceae (Otsuka et al. 2003). The third sub-fraction $(4.2 \mathrm{mg}$ ) with a green fluorescence (UV $366 \mathrm{~nm}$ ) had five major compounds: 9-hydroxy-4-megastigmen-3-one (RT = $11.6 \mathrm{~min}, \mathrm{~m} / \mathrm{z} 210)$, isololiolide $(\mathrm{RT}=12.0 \mathrm{~min}, \mathrm{~m} / \mathrm{z}$ 196), (-) loliolide ( $\mathrm{RT}=12.3 \mathrm{~min}, \mathrm{~m} / z$ 196), palmitic $\operatorname{acid}(\mathrm{RT}=14.1 \mathrm{~min}, \mathrm{~m} / \mathrm{z} 256)$ and lupeol $(\mathrm{RT}=28.4 \mathrm{~min}$, $\mathrm{m} / \mathrm{z}$ 189). The three first compounds are norisoprenoids registered in species of seaweed and higher plants. Most importantly, this is the first report of the occurrence of (-)-loliolide in the genus Pera and the second occurrence in the family Euphorbiaceae. The first occurrence of this compound for Euphorbiaceae was described in Alchornea glandulosa Endl. \& Poeppig (Conegero et al. 2003). Okunade \& Wiemer (1985) demonstrated that (-)-loliolide isolated from Xanthoxyllum setulosum P. Wilson (Rutaceae) is a potent leafcutter repellent. The natural occurrence of loliolide is mainly reported for plant material (Ghosal et al. 1976). They have become especially known as flavor compounds in tea and tobacco (Bricout et al. 1967, Kodama et al. 1982, Roberts \& Rohde 1972). Loliolide is also reported to occur in the marine mollusk Dolabella ecaudata (Pettit et al. 1980).

Lupeol was also found in another species of the genus Pera. Fournet et al. (1992) reported this compound in $P$. benensis, which shows antileishmaniasis activity.

In conclusion, this work demonstrated that leaves of Pera glabrata contain a great amount of caffeine that may act as a chemical defense against fungal pathogens and can enhance memory and learning of Alzheimer's disease patients.

Acknowledgments - We are grateful to Dr Inês Cordeiro, SP Herbarium, for the identification of Pera glabrata (Schott) Baill. This work was also supported by Fapesp (Proc. 2003/02176-7). Daisy Maria Bentes de Paula is grateful to Pibic/CNPq for providing a scholarship. Maria Cláudia Marx Young is grateful to CNPq for research fellowship. Elaine Monteiro Cardoso Lopes thanks Prodoc/Capes for providing a post-doctoral fellowship through the postgraduate program on Biodiversidade Vegetal e Meio Ambiente of the IBt.

\section{References}

ARENDASH, G.W., SCHLEIF, W., REZAI-ZADEH, K., JACKSON, E.K., ZACHARIA, L.C., CRACCHIOLO, J.R., SHIPPY, D. \& TAN, J. 2006. Caffeine protects Alzheimer's mice against cognitive impairment and reduces brain $\beta$-amyloid production. Neuroscience 142:941-952.

ASHIHARA, H., SANO, H. \& CROZIER, A. 2008. Caffeine and related purine alkaloids: biosynthesis, catabolism, function and genetic engineering. Phytochemistry 69:841-856.

BARROSO, G.M., PEIXOTO, A.L., COSTA, C.G., ICHASO, C.L.F., GUIMARÃES, E.F. \& LIMA, H.C. DE. 1984. Sistemática de angiospermas do Brasil. Imprensa Universitária da Universidade Federal de Viçosa, Viçosa, v.2.

BRICOUT, J., VIANI, R., MUGGLER-CHAVAN, F., MARION, J.P., RWYMOND, D. \& EGLI, R.H. 1967. Sur la composition de l'arome de thé noir II. Helvetica Chimica Acta 50:1517-1522.

CONEGERO, L.S., IDE, R.M., NAZARI, A.S., SARRAGIOTTO, M.H., DIAS FILHO, B.P., NAKAMURA, C.V., CARVALHO, J.E. \& FOGLIO, M.A. 2003. Constituintes químicos de Alchornea glandulosa (Euphorbiaceae). Química Nova 26:825827.

CRONQUIST, A. 1981. An integrated system of classification of flowering plants. Columbia University Press, New York.

DALY, J.W. 2007. Caffeine analogs: biomedical impact. Cellular and Molecular Life Science 64:2153-2169.

ELLMAN, G.L., COURTNEY, K.D., ANDRES, V. JR. \& FEATHERSTONE, R.M. 1961. A new and rapid colorimetric determination of acetylcholinesterase activity. Biochemical Pharmacology 7:88-95.

FOURNET, A., ANGELO, A., MUÑOZ, V., ROBLOT, F., HOCQUEMILLER, R. \& CAVÉ, A. 1992. Biological and chemical studies of Pera benensis, a Bolivian plant used in folk medicine as a treatment of cutaneous leishmaniosis. Journal of Ethnopharmacology 37:159-164.

FRANCIS, P.T., PALMER, A.M., SNAPE, M. \& WILCOCK, G.K. 1999. The cholinergic hypothesis of Alzheimer's disease: a review of progress. Journal Neurology Neurosurgery Psychiatry 66:137-147.

GHOSAL, S., SINGH A.K. \& CHAUDHURI, R.K. 1976. Chemical constituents of Gentianaceae XX: natural occurrence of (-)-loliolide in Canscora. Journal of Pharmaceutical Sciences 65:1549-1551.

HAMBURGER, M. \& HOSTETTMANN, K. 1991. Bioactivity in plants: the links between phytochemistry and medicine. Phytochemistry 12:3864-3874.

HOMANS, A.L. \& FUCHS, A. 1970. Direct bioautography on thin-layer as method for detecting fungitoxic substances. Journal of Chromatography 51:327-329. 
HOSTETTMANN, K. 1998. Strategy for the biological and chemical evaluation of plant extracts. Pure and Applied Chemistry 70:23-27.

HOSTETTMANN, K., MARSTON, A., MAILLARD, M. \& HAMBURGER, M. 1995. Phytochemistry of plants used in traditional medicine. Clarendon Press, Oxford.

JOLY, A.B. 1976. Botânica: introdução à taxonomia vegetal. $3^{\text {th }}$ ed., Editora Nacional, São Paulo.

KODAMA, H., FUJIMORI, T. \& KATÕ, K. 1982. Isolation of a new terpene glucoside, loliolide- $\beta$-D-glucopyranoside from flue-cured tobacco. Agricultural and Biological Chemistry 46:1409-1411.

LORENZI, H. 2002. Árvores brasileiras: manual de identificação e cultivo de plantas arbóreas nativas do Brasil. Editora Plantarum, Nova Odessa, v.2.

MAIA, L. \& DE MENDOUCA, A. 2002. Does caffeine intake protect from Alzheimer's disease? European Journal of Neurology 9:377-382.

MARSTON, A., KISSLING, J. \& HOSTETTMANN, K. 2002. A rapid TLC bioautographic method for the detection of acetylcholinesterase and butyrylcholinesterase inhibitors in plants. Phytochemical Analysis 13:51-54.

MIYASE, T., UENO, A., TAKIZAWA, N., KOBAYASHI, H. \& OGUCHI, H. 1988. Studies on the glycosides of Epimedium grandiflorum Morr. var. thunbergianum (Miq.) Nakai III. Chemical \& Pharmaceutical Bulletin 36:2475-2484.

MORS, W.B. \& RIZZINI, C.T. 1966. Useful plants of Brazil. Holden-Day Inc., San Francisco.

NATHANSON, J.A. 1984. Caffeine and related methylxanthines: possible naturally occurring pesticides. Science 226:184.

OKUNADE, A.L. \& WIEMER, D.F. 1985. (-)-Loliolide, an ant-repellent compound from Xanthoxyllum setulosum. Journal of Natural Products 48:472-473.

OTSUKA, H., KIJIMA, H., HIRATA, E., SHINZATO, T., TAKUSHI, A., BANDO, M. \& TAKEDA, Y. 2003. Glochidionionosides A-D: Megastigmane glucosides from leaves of Glochidion zeylanicum (Gaertn.) A. Juss. Chemical \& Pharmaceutical Bulletin 51:286290.

PETTIT, G.R., HERALD, C.L., ODE, R.H., BROWN, P., GUST, D.J. \& MICHEL, C. 1980. The isolation of loliolide from an Indian ocean opisthobranch mollusc. Journal of Natural Products 43:752-755.
QUIK, M. \& JEYARASASINGAM, G. 2000. Nicotinic receptors and Parkinson's disease. European Journal of Pharmacology 393:223-230.

RAHALISON, L., HAMBURGER, M., MONOD, M., FRENK, E. \& HOSTETTMANN, K. 1994. Antifungal tests in phytochemical investigations comparison of bioautographic methods using phytopatogenic and human pathogenic fungi. Planta Medica 60:41-44.

RATES, S.M.K. 2001. Metilxantinas. In Farmacognosia: da planta ao medicamento (C.M.O. Simões, E.P. Schenkel, G. Gosmann, J.C.P. Mello, L.A. Mentz \& P.R. Petrovick, eds.). $3^{\text {th }}$ ed., Editoras UFGS e UFSC, Porto Alegre/ Florianópolis, p.733-749.

RHEE, K., MEENT, M. VAN DE, INGKANINAN, K. \& VERPOORTE, R. 2001. Screening for acetylcholinesterase inhibitors from Amaryllidaceae using sílica gel thin-layer chromatography in combination with bioactivity staining. Journal of Chromatography A 915:217-223.

RIOS, J.L., RECIO, M. \& VILLAR, A. 1988. Screening methods for natural products with antimicrobial activity: a preview of the literature. Journal of Ethnopharmacology 23:127-149.

ROBERTS, D.L. \& ROHDE W.A. 1972. Isolation and identification of flavor components of burley tobacco. Tobacco Science 16:107-112.

SILVA, R.S., RICHETTI, S.K., SILVEIRA, V.G., BATTASTINI, A.M.O., BOGO, M.R., LARA, D.R. \& BONAN, C.D. 2008. Maternal caffeine intake affects acetylcholinesterase in hippocampus of neonate rats. International Journal of Developmental Neuroscience 26:339-343.

SOUSA, M.P., MATOS, M.E.O., MATOS, F.J.A., MACHADO, M.I.L. \& CRAVEIRO, A.A. 1991. Constituintes químicos ativos de plantas medicinais brasileiras. Edição UFC/Laboratório de Produtos Naturais, Fortaleza.

WEHRLI, F.W. \& NISHIDA, T. 1979. The use of carbon13 nuclear magnetic resonance spectroscopy in natural products chemistry. In Progress in the chemistry of organic natural products. (W. Herz, H. Grisebach, \& G.W. Kirby, eds.). Springer-Verlag, New York.

YUVAMOTO, P.D. \& SAID, S. 2007. Germination, duplication cycle and septum formation are altered by caffeine, caffeic acid and cinnamic acid in Aspergillus nidulans. Microbiology 76:735-738. 